DOI https://doi.org/10.30525/978-9934-26-173-2-50

\title{
СУЧАСНІ ПЕДАГОГІЧНІ МЕТОДИ ВИКЛАДАННЯ УКРАЇНСЬКОЇ МОВИ ЯК ІНОЗЕМНОЇ НА ДОВУЗІВСЬКОМУ ЕТАПІ ПІДГОТОВКИ В УМОВАХ ДІДЖИТАЛІЗАЦЇ̈ ОСВІТИ
}

\author{
Черновол О. Г. \\ викладач Центру підготовки іноземних громадян \\ Запорізький державний медичний університет \\ м. Запоріжжя, Украӥна
}

Внаслідок процесу глобалізації та інформаційної революції у сфері освіти перед закладами вищої освіти постали нові виклики, пов'язані 3 активним впровадженням у навчальний процес перспективних освітніх моделей навчання та методів викладання української мови як іноземної на довузівському етапі підготовки в умовах діджиталізації освіти.

Ефективність і раціональність організації навчального процесу мають базуватися: на чітких нормативних, навчально-методичних засадах; на дидактичній координації вивчення мови на довузівському етапі та на першому курсі вищої освіти; узгодження навчальних програм українською мовою для довузівського етапу та основного етапу підготовки іноземців; врахування сучасних освітніх потреб. Відповідно до цих вимог будується організаційно-методична модель навчання української мови в Центрі міжнародної освіти [1].

До сучасних педагогічних методів викладання української мови як іноземної на довузівському етапі підготовки в умовах діджиталізації освіти належать такі: граматико-перекладний метод, аудіо-лінгвальний метод, аудіовізуальний метод, лінгво-соціокультурний метод, проблемно-дослідницький метод, проектний метод, цифровий метод та логічні методи (індуктивний та дедуктивний) [2].

Практичні заняття української мови як іноземної мови на довузівському етапі підготовки проводяться на основі різних форматів наочності та технічного забезпечення: 3 використанням наочності, представленої на папері; з використанням презентацій або медіапрезентацій; з використанням інтерактивної дошки або персональних комп'ютерів, необхідних для доступу до Інтернет-ресурсів як джерела навчальних матеріалів; на основі аудіо-або відеоблоків; на основі випадків проблемних мовленнєвих ситуацій, представлених у аудіо- або відеоформі. Набувають популярності нетрадиційні форми проведення практичних мовних занять, такі як: урок-екскурсія, урок інтелектуальної гри, урок-диспут, урок-олімпіада тощо. 
Інноваційні підходи мовної підготовки іноземців мають реалізовувати наступні завдання: сформувати комунікативну компетентність іноземних студентів; сформувати загально-професійну компетентність у контексті майбутньої професійної діяльності; сформувати соціокультурну компетентність у контексті соціально-культурної адаптації іноземців до нових умов життя та навчання в Україні та до національної системи освіти.

Відповідно до цих завдань зміст курсу української мови та його структура визначається на основі таких аспектів навчання, як загальнолітературна мова або нейтральний стиль мовлення, науковий стиль мовлення та реалізація розмовної практики в соціокультурному аспекті. Усі аспекти курсу української мови викладені в методичних матеріалах, які представлені у форматах навчально-методичних комплексів, які представлені блоками матеріалів методичного та дидактичного, навчально-навчального характеру [1].

Таким чином, методична складова методів викладання української мови як іноземної на довузівському етапі підготовки має характеризуватися: різноманітністю та варіативністю, можливістю модифікувати навчальний матеріал; відповідністю рівнів мовної підготовки іноземних студентів вимогам нових освітніх програм та європейським стандартам; складністю викладу навчального матеріалу відповідно до ранжування, пріоритетності та домінування виду мовленнєвої діяльності, необхідної для досягнення успіху у формуванні вмінь і навичок з усіх видів мовлення.

\section{Література:}

1. Leshchuk S.I., Belikov A.B., Muliar V.I., Oleksin Yu.P., Mitina L.S. et al. Innovative approaches to personal development and health improvement. Monographic series «European Science». Book 4. Part 10. 2021. $184 \mathrm{p}$.

2. Muratova G., Abraimova N. The use of information-communication technologies and modern methods in teaching a foreign language. Mental Enlightenment Scientific-Methodological Journal. 2020, Vol. 2020, Iss. 2 , Article 20. pp. 175-181. URL: https://uzjournals.edu.uz/tziuj/vol2020/iss2/20 (дата звернення 26.11.2021). 